\title{
Export-import dynamics of zooplankton on a coral reef in Palau
}

\author{
W. M. Hamner ${ }^{1, *}$, P. L. Colin ${ }^{2}$, P. P. Hamner ${ }^{3}$ \\ ${ }^{1,3}$ Department of Ecology and Evolutionary Biology, University of California Los Angeles, Box 951606, Los Angeles, \\ California 90095-1606, USA \\ ${ }^{2}$ Coral Reef Research Foundation, PO Box 1765, Koror, Palau PW 96940
}

\begin{abstract}
Although coral reefs are widely viewed as oases in an oceanic desert, we demonstrate that the oceans around coral reefs in Palau are not deserts devoid of food, nor are coral reefs oases isolated from the surrounding sea. On flood tides, oceanic zooplankton advects onto the Palau barrier reef, where it is consumed by a wall of planktivorous fish. Similarly, on ebb tides lagoon zooplankton is consumed as it advects across the reef flat. Coral reef planktivores ingest zooplankton imported from both the sea and the lagoon, but coral reef fish also export meroplanktonic fish eggs that disperse offshore. Every day about 30 species of reef fishes, some forming spawning aggregations (parrotfish and surgeonfish), spawn at the forereef when the tide turns, releasing clouds of buoyant eggs and sperm into the ebb-tide waters that flow off the reef flat. Fish eggs disperse seaward, but remain entrained within several kilometers of the reef in a tidal, neritic water mass, separated from oceanic currents by tidal fronts. Flood tides return fish embryos and offshore zooplankton to the reef. The flux of materials between oceanic, neritic, and lagoon waters near coral reefs must be reexamined.
\end{abstract}

KEY WORDS: Coral reef zooplankton $\cdot$ Fish spawning $\cdot$ Egg dispersal $\cdot$ Palau

Resale or republication not permitted without written consent of the publisher

\section{INTRODUCTION}

Coral reefs exchange water, plankton, and nonliving materials with the adjacent ocean and lagoon. Early literature (Odum 1953, Odum \& Odum 1955, Johannes et al. 1972, Johannes \& Gerber 1974) claimed coral atolls were 'oases of life in an oceanic desert', energetically closed ecosystems with limited exchange with the surrounding sea, retaining production, recycling nutrients, and flourishing in oligotrophic oceans. Unfortunately this paradigm has been generalized to all categories of coral reefs. Barrier reefs, however, surround high islands or occur along continental margins, where terrestrial nutrients discharge into barrier reef lagoons with longer residence times and higher productivity than exhibited by coral reef atoll lagoons (Birkeland 1982, Sammarco \& Crenshaw 1984). Our data demonstrate that the barrier reef in Palau is strongly connected to the islands, lagoon, and sea, a finding supportive of more recent research (Pickard
1986, Hamner et al. 1988, Wolanski \& Hamner 1988, Sorokin 1990, Kinsey 1991, Hatcher 1997). We assess import and export of zooplankton for a barrier reef around high islands in Palau, at a site where circulation is controlled by tidal currents, and we document changes in zooplankton composition as it crosses the reef. We also describe episodic spawning of reef fishes with planktonic eggs and evaluate contribution of fish eggs to the total plankton biomass exported from the barrier reef each day.

At Enewetak in the mid-Pacific Ocean (Odum \& Odum 1955, Johannes \& Gerber 1974, Atkinson et al. 1981) and Davies Reef in the Great Barrier Reef (Pickard 1986, Hamner et al. 1988) trade winds and wave-overtopping generate an almost constant unidirectional flow from ocean to lagoon. Our study area in Palau (see Fig. 1), however, is protected from easterly waves by barrier reef topography and from southeasterly swells by an offshore, submerged barrier reef, and semidiurnal tides control flow from sea to lagoon 
(flood) and lagoon to sea (ebb), allowing assessment of export and import of zooplankton across the reef.

We expected in Palau that on flood tides ocean waters would advect onto the reef, where mesozooplankton would be consumed by planktivorous fish and filter feeders (Emery 1968, 1973, Hobson \& Chess 1978, Hamner et al. 1988, Sorokin 1990, Holzman \& Genin 2003, Fabricius \& Metzner 2004, Heidelberg et al. 2004). We also expected that breaking waves on the forereef (modest at our study site) and grazing fishes would generate modest amounts of reef detritus, which would be transported across the reef toward the lagoon (Alongi 1997, Crossman et al. 2001, Yahel et al. 2002). On ebb tides, lagoon mesozooplankton, different from that found on reefs or in the open sea (Emery 1968, Tranter \& George 1972, Hobson \& Chess 1978, 1979, Hamner \& Carleton 1979), flows onto the Palau barrier reef, and we expected that lagoon zooplankton would also be consumed by planktivores in transit across the reef.

In Palau a suite of 30 to 40 species of reef fishes, principally surgeonfishes, parrotfishes, and wrasses, spawn for a few hours after high tide along the forereef throughout the year (P. L. Colin pers. obs.). At our study site, the parrotfish Chlorurus sordidus and the 2 surgeonfishes Acanthurus nigrofuscus and Ctenochaetus striatus dominate spawning aggregations at intervals of about $50 \mathrm{~m}$ along the reef face (Colin \& Bell 1991, Domeier \& Colin 1997, P. L. Colin pers. obs.). The eggs of the scarids Chlorurus and Scarus are spindleshaped, making them easy to distinguish, while those of most other reef fishes (acanthurids, labrids, some scarids and other families) are spherical. Both types of eggs are transparent, buoyant, and relatively large (C. sordidus: $1.38 \times 0.47 \mathrm{~mm}$; Acanthurus sp.: $0.58 \mathrm{~mm}$ diameter), and are collected readily with neuston nets (Zaitsev 1971, Omori \& Ikeda 1984). We hypothesized that on falling tides a substantial biomass of these fish eggs would be exported from the forereef into the open sea, because the spawning fish aggregations are invariably seaward of most planktivorous fish along the forereef.

We quantified import and export of mesozooplankton across the Palau barrier reef and documented changes in zooplankton assemblages as they advected across the reef. In addition, we documented episodic spawning of reef fishes with planktonic eggs, and quantified the contribution of meroplanktonic fish eggs exported from, and to a lesser degree, imported onto the reef each day. Although our sampling effort emphasized collection of fish eggs exported offshore during ebb tide, we also collected mesozooplankton from the lagoon and from the sea during flood and ebb tides, permitting us to address the issue of tidal export-import dynamics.

\section{MATERIALS AND METHODS}

We sampled for fish eggs and mesozooplankton between the open sea, the eastern barrier reef of Palau (Fig. 1), and the lagoon during flood and ebb tides during the day for $35 \mathrm{~d}$ between 10 July and 14 August 2000, collecting 132 samples. We used moored, metered, $0.305 \mathrm{~mm}$ neuston nets, with $0.305 \mathrm{~mm}$ mesh plankton sock cod ends, to fish at the surface in cross reef tidal currents $1 \mathrm{~km}$ south of Malakal Lighthouse, at the entrance to Malakal Harbor (Fig. 2). Paired nets were moored $10 \mathrm{~m}$ apart, seaward of the forereef and in the lagoon. Permanent moorings marked by a surface float were used to station the nets. Forereef nets were placed $80 \mathrm{~m}$ seaward of the reef crest over a $15 \mathrm{~m}$ bottom near deep water (Fig. 3). Lagoon nets were in $1 \mathrm{~m}$ of water at low tide above a sandy bottom $5 \mathrm{~m}$ from the backreef. Floats held the top of the $65 \times 70 \mathrm{~cm}$ $\left(0.455 \mathrm{~m}^{2}\right)$ nets slightly above the surface, with the lower edge $65 \mathrm{~cm}$ below the surface. General Oceanic flow meters were suspended in each net $30 \mathrm{~cm}$ below the surface. Tidal currents fished the nets. The tide in Palau is semidiurnal, with a maximum amplitude of 1.0 to $2.0 \mathrm{~m}$ at neap and spring tides. As a temporary tide gauge at our study site matched tide recordings in Malakal Harbor $5 \mathrm{~km}$ away, we used the Malakal Harbor records in our study.

We sampled fish eggs and mesozooplankton during the first $2 \mathrm{~h}$ of ebb tide for 35 consecutive days, over an

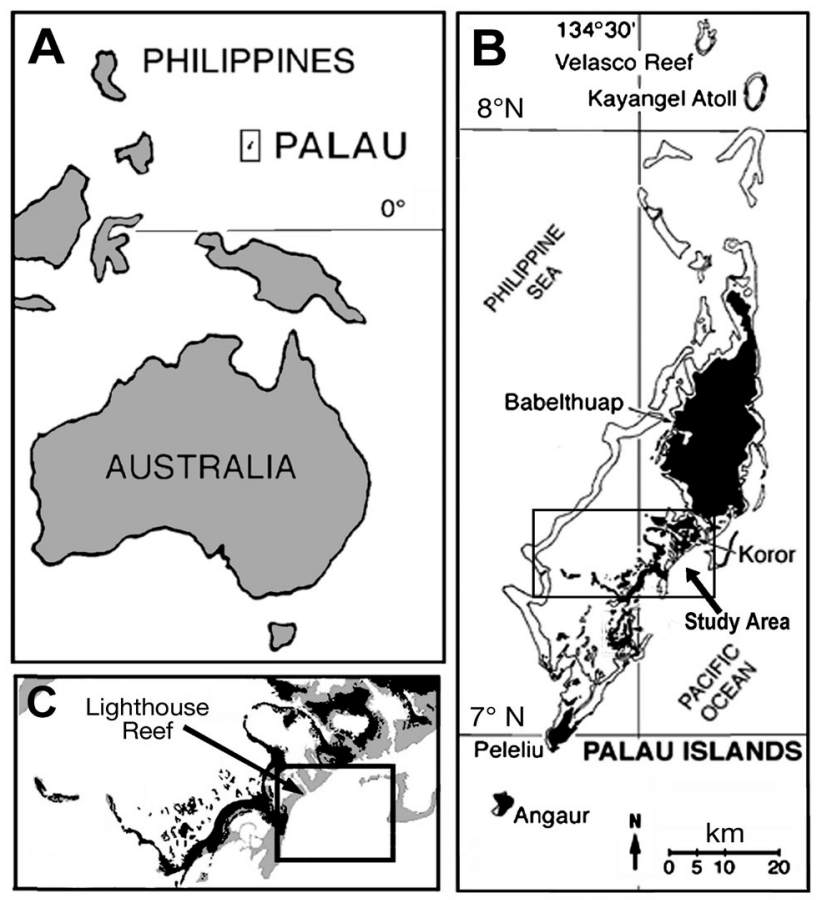

Fig. 1. Palau (A) and the study area (B) on the southeastern barrier reef $(\mathrm{C})$. Black area in $(\mathrm{B})$ and $(\mathrm{C})$ is land; white area in (B) and grey in (C) shows reefs 

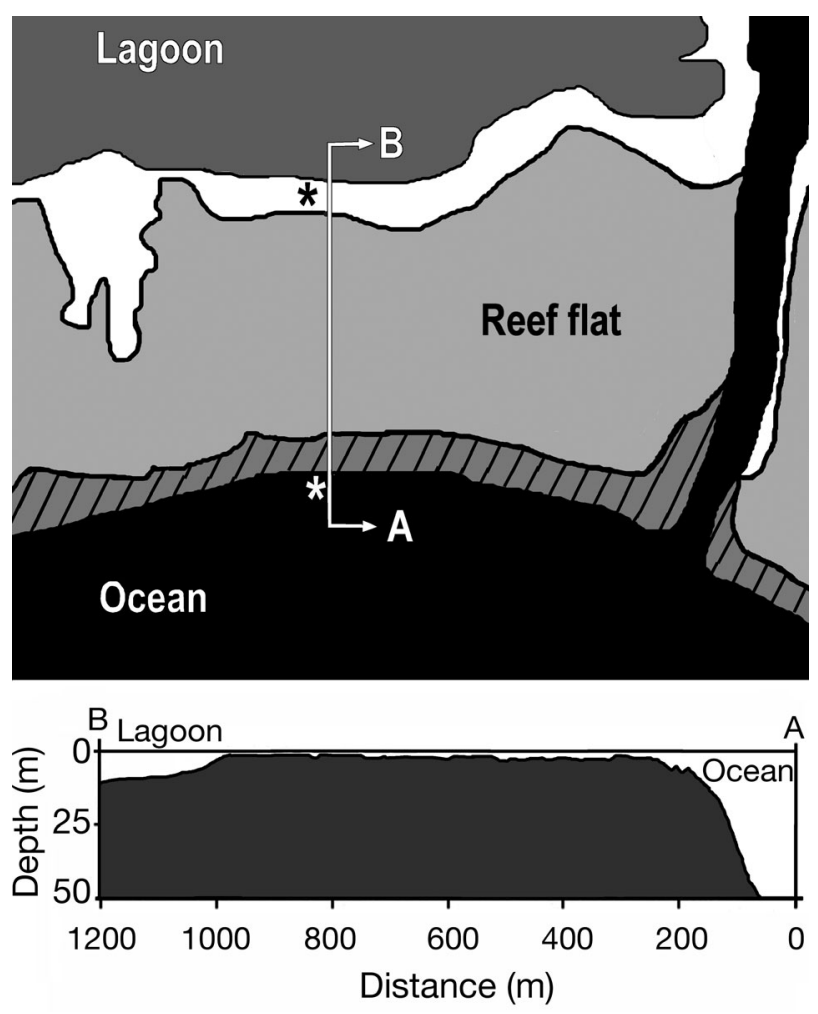

Fig. 2. Location of study transect, (A-B) on Lighthouse Reef, Palau. *: locations where nets were moored

entire lunar period, from 10 July to 13 August 2000 (see Fig. 4). On 14 occasions we fished the first $2 \mathrm{~h}$ of ebb tide (when most fish spawned), then removed the nets and recorded flow meter data, washed net plankton into plankton socks, preserved the socks and zooplankton in $2 \%$ formalin, attached clean socks, and fished the nets for a further $4 \mathrm{~h}$. Handling time was $5 \mathrm{~min}$. We did not fish nets for precisely 2, 4, or $6 \mathrm{~h}$, so all flow meter data and wet weights were adjusted to 2,4 , or $6 \mathrm{~h}$ per linear meter of reef or presented as $\mathrm{mg} \mathrm{m}^{3}$ (see Table 1). We collected no plankton on 14 July because the fish shifted from spawning at dusk on 13 July (16:40 to $18: 40 \mathrm{~h}$ ) to dawn on 15 July (06:00 to $08: 10$ h). Data for July 14 (see Fig. 4) were interpolated.

Flow through all nets was measured using General Oceanic flow meters, with low-speed rotors calibrated over a known distance by hanging the flow meters $2 \mathrm{~m}$ below a boat at speeds similar to flow over the reef. Although initial calibration was acceptable, meters in nets were often fouled by flotsam. Less often, wave chop caused rotor spinning and/or introduced air into water-filled flow meters, producing meter error. We calculated percentage difference between paired meters in adjacent nets, normalized for a $2 \mathrm{~h}$ period on all days when both meters had readings above or below 5000 revolutions in $2 \mathrm{~h}$. When both meters rotated rapidly (>5000 rev. $2 \mathrm{~h}^{-1}$ ), their difference was $11.3 \%(\mathrm{n}=14)$; when rotating slowly $\left(<5000\right.$ rev. $\left.2 \mathrm{~h}^{-1}\right)$ the difference was $52.6 \%(\mathrm{n}=11)$, 5 times more variable. Although we used large, slowflow rotors, these meters perform erratically at very slow speeds. Consequently, for paired nets, we always used the flow rate and zooplankton data (wet weight $\mathrm{m}^{-3}$ ) from the net with the higher meter reading. Although we use flow meter data and wet weight $\mathrm{m}^{-3}$ throughout our analysis and discussion, we also emphasize the quantity of zooplankton collected per net per unit time (i.e. during the first $2 \mathrm{~h}$ or last $4 \mathrm{~h}$ of ebb tide, or in a $6 \mathrm{~h}$ tidal cycle).

An additional flow meter was moored next to a large aggregation of spawning fish every day, adjusted by a diver at $15 \mathrm{~min}$ intervals so that it was always $1 \mathrm{~m}$ below the surface for the first $2 \mathrm{~h}$ of ebb tide. This diver also collected information every day for $35 \mathrm{~d}$ on species and abundance of fishes in the spawning aggregation (P. L. Colin unpubl.). The reef-top flow meter was moored taut between the reef and a large subsurface float, it rotated smoothly, independent of winds or waves, and it regularly recorded ebb flows 2 to 5 times faster than did flow meters in offshore nets (see Fig. 4A).

Vertical distribution of fish eggs on ebb tide was determined from 2 sets of horizontally stratified plankton samples collected $1 \mathrm{~h}$ after high tide by swimming a plankton net at the surface and at $3 \mathrm{~m}$ depth intervals over a $20 \mathrm{~m}$ transect, across and back between the

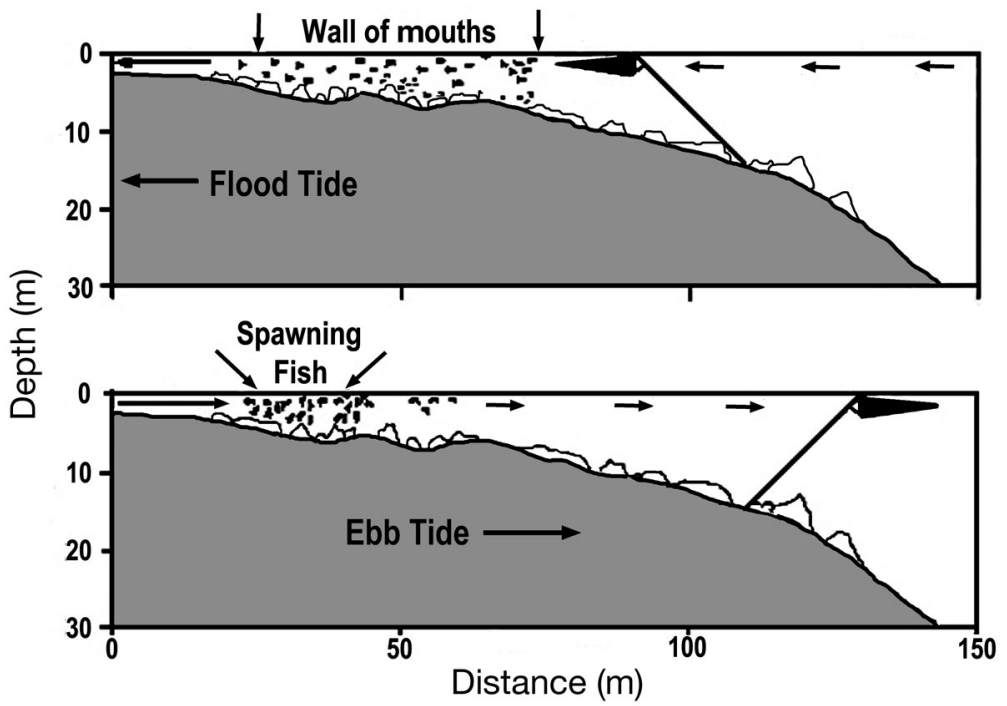

Fig. 3. Diagram of forereef with location of moored zooplankton nets during flood and ebb tides (solid line; upper and lower panel, respectively). Note planktivorous fishes ('wall-of-mouths') present only on flood tides 
2 seaward mooring lines. Fish eggs are buoyant, so the deepest samples (at $10 \mathrm{~m}$ ) were collected first to reduce net contamination. After each sample had been collected, we shook the net vigorously from front to back to move plankton into the sock, placed the sock and zooplankton into a labeled jar, attached a clean plankton sock to the sleeve at the cod end, and swam the net at the next shallower depth. Most fish eggs (90\%) were in the top $4 \mathrm{~m}_{i} 60 \%$ of these were in the top meter. Thus, our moored, floating plankton nets undersampled fish eggs (and probably other mesozooplankton also) by about $40 \%$. Stratified samples were collected on a calm day without waves and minimal vertical mixing of the water column. On windy days with surface waves, fish eggs and zooplankton flowing off the reef would mix deeper, with greater undersampling.

Zooplankton samples and collection socks were preserved in $2 \%$ formalin in the field. Plankton socks were washed later, and non-zooplankton (Sargassum, eel grass, large algal fragments, coral sand, and lagoon debris) was removed prior to weighing. Wet samples were weighed to the nearest $0.1 \mathrm{~g}$ after draining for 2 min. Sample weights were converted to weight per cubic meter (moored nets sampled $0.455 \mathrm{~m}^{2}$ ). Samples were mixed with $500 \mathrm{ml}$ of water and stirred for $2 \mathrm{~min}$ with a magnetic stirrer, then zooplankton in a $1 \mathrm{ml}$ subsample were counted. We used data from 15 consecutive days (16 to 30 July) to evaluate counting errors for eggs, which were $3.0 \%$ for spherical and $2.2 \%$ for spindle-shaped eggs.

For statistical analysis of mesozooplankton assemblages, we evaluated samples for 5 combinations of site location and tidal stage. These were designated as Ocean Ebb-2 ( $\mathrm{n}=31$ ), collected during the first $2 \mathrm{~h}$ of ebb tide from the ocean side of the forereef, and Ocean Ebb-4 ( $\mathrm{n}=15)$, for samples from the same location but during the last $4 \mathrm{~h}$ of ebb tide. We analyzed zooplankton for the entire $6 \mathrm{~h}$ of flood tide from the ocean site (Ocean Flood, $\mathrm{n}=9$ ), for the $6 \mathrm{~h}$ of ebb tide from the lagoon site (Lagoon Ebb, $\mathrm{n}=9$ ), and also from the lagoon during the entire flood tide (Lagoon Flood, $\mathrm{n}=6$ ). Zooplankton were subsampled, categorized initially into 25 taxonomic groups, with approximately 200 individuals of the most common taxa counted, although only 13 of the 25 taxa were sufficiently abundant for further statistical consideration (see Table 2). We elected to evaluate statistical properties via routine SPSS 11.0 procedures rather than more sophisticated approaches (Carleton et al. 2001, Legendre \& Gallagher 2001) because we collected our samples according to a balanced, replicated sampling design and because we intentionally eliminated rare taxa from statistical analysis (Legendre \& Gallagher 2001). Eliminating rare spe- cies permitted use of raw data throughout rather than use of data subjected to log-transformation, which produces data sets with which we are not comfortable. Sophisticated statistics certainly do permit subtle interpretations of rare taxa, but most articles about zooplankton seldom discuss rare species. We obtained descriptive statistics for 5 sampling site-time combinations. One-way ANOVA demonstrated that 8 of the 13 plankton categories analyzed (see Table 2) showed highly significant differences $(<0.01)$ between groups. Dendrograms illustrate the quantitative linkages between samples and between sample categories (see Fig. 5). Discriminate analysis for within-group covariance and canonical discriminate functions of these 8 categories are shown as a scatter plot (see Fig. 6).

We recorded wet weights and counted subsamples of mesozooplankton and recently fertilized fish eggs collected on 35 consecutive days for all of the Ocean Ebb-2 nets (see Fig. 4B), counting both round and spindle-shaped eggs (see Fig. 4C). To follow dispersal of eggs and mesozooplankton exported on ebb tides, we used cross-vane surface drogues, with the bottom of the vanes at $0.7 \mathrm{~m}$ depth. Drogues were tied to a sparbuoy, with a flag $2 \mathrm{~m}$ above the water for visibility. We released drogues off the forereef next to newly spawned fish eggs and followed drogues with a boat, recording drifter positions with GPS every 30 min (see Fig. 7).

\section{RESULTS AND DISCUSSION}

In Palau, water moves between the lagoon and the ocean both as channel-flow through reef passes such as Malakal Channel (Fig. 2) and as sheet-flow across barrier reefs at all but lowest tides; our reef transect was emergent during spring low tide. We sampled zooplankton with 2 pairs of neuston nets that fished on rising and falling tides on both outer and inner margins of the barrier reef, documenting zooplankton that arrived at the reef, that survived cross-reef transport, and that left the reef (Fig. 3). On rising tides, seaward nets captured zooplankton coming from ocean to reef, seaward of planktivorous fishes, while lagoon nets captured materials that flowed over the reef from ocean to lagoon. On falling tides, lagoon nets captured zooplankton from the lagoon, while seaward nets captured plankton that survived the passage across the reef and fish eggs that were spawned at the forereef. There is a 'wall of mouths' of planktivorous fishes along the ocean side of the barrier reef in Palau on flood tides, but not on ebb tides (Fig. 3). Planktivorous fishes never occurred along the back reef. 


\section{Import of zooplankton from the sea on flood tides}

During flood tide, ocean water moved slowly toward the reef $\left(1.4 \pm 1.1 \mathrm{~cm} \mathrm{~s}^{-1}\right)$, with $299.5 \pm 263.9 \mathrm{mg}$ $\mathrm{m}^{-3}$ mesozooplankton (Ocean Flood; Table 1, Fig. 4B). During a $6 \mathrm{~h}$ flood period, $71.7 \pm 63.0 \mathrm{~g}$ zooplankton were imported onto each linear meter of forereef. Ocean Flood samples (Tables 1 \& 2) had large copepods $(29.9 \%)$, appendicularians $(29.0 \%)$, chaetognaths $(26.5 \%)$, and developing fish eggs (both round and spindle-shaped; $6.6 \%$ ), typical of tropical oceanic water seaward of diurnal planktivorous fishes (Emery 1968, 1973, Hobson \& Chess 1978, Hamner et al. 1988). There was no reef debris (filamentous algae, fish feces, sand) in water reaching the reef from the sea.

Flood tide waters passed through a 'wall of mouths' of planktivorous fishes at the forereef (Emery 1973, Hamner et al. 1988), then flowed over the reef crest, across the broad reef flat, and into the lagoon. Biomass $\mathrm{m}^{-3}$ of zooplankton flowing into the lagoon was 7 times lower than biomass seaward of the 'wall of mouths' $\left(40.7 \pm 21.5 \mathrm{mg} \mathrm{m}^{-3}\right.$; Lagoon Flood, Table 1). Flood tide current in the lagoon after crossing the reef was faster than offshore (6.2 \pm $3.7 \mathrm{~cm} \mathrm{~s}^{-1}$ vs. $1.4 \pm 1.1 \mathrm{~cm} \mathrm{~s}^{-1}$ ). Lagoon nets collected $43.1 \pm 19.9 \mathrm{~g}$ zooplankton per linear meter of reef during $6 \mathrm{~h}$ of flood tide, half the amount imported onto the forereef front in the same time (Table 1). A large percentage of the biomass entering the lagoon was reef debris (algal fragments and sediment; Alongi 1997, Crossman et al. 2001, Yahel et al. 2002). Further, the composition of living zooplankton biomass entering the lagoon was different from that captured seaward of the reef, consisting of small copepods $(66.4 \%)$, small chaetognaths $(11.2 \%)$, small appendicularians $(9.4 \%)$, zoea $(3.2 \%)$, fish eggs $(2.3 \%)$, and foraminifera $(1.8 \%)$ (Table 2$)$. Copepods captured in Lagoon Flood nets were significantly
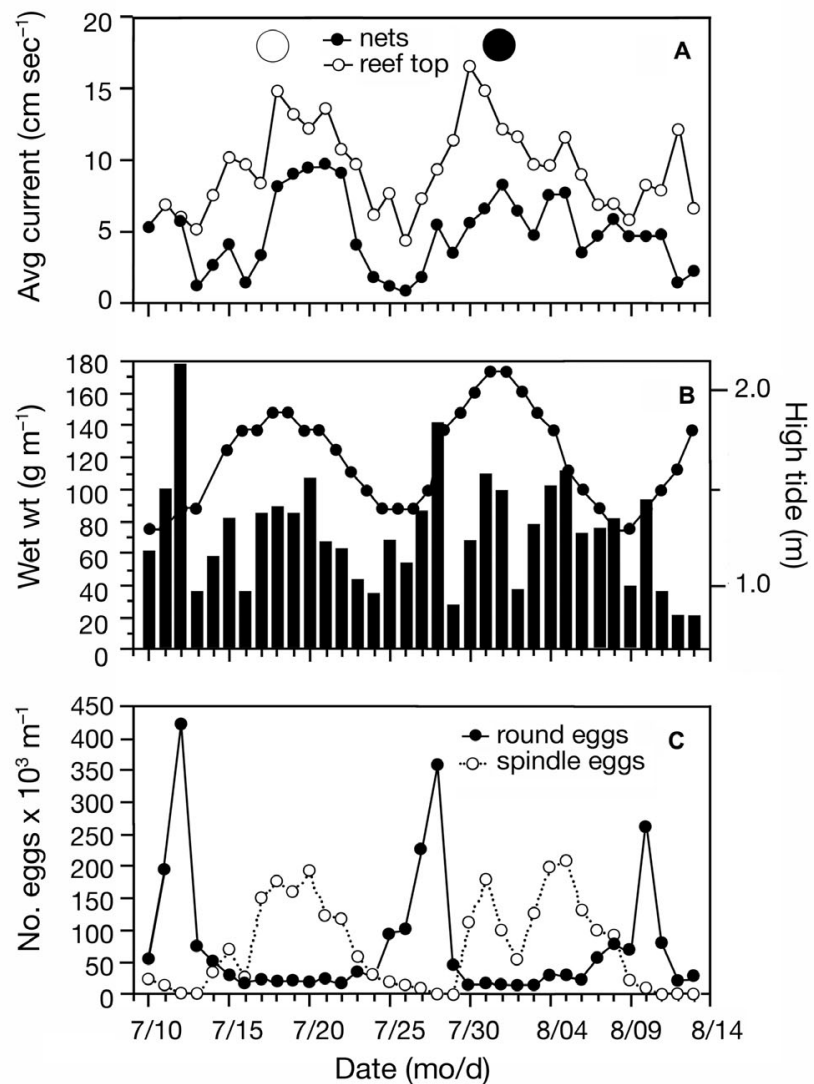

Fig. 4. Forereef dynamics during ebb tide. (A) Average current speed during first $2 \mathrm{~h}$ of ebb tide on reef top and in plankton nets $50 \mathrm{~m}$ seaward (large open circle: full moon; large filled circle: new moon). (B) Mesozooplankton exported ( $\mathrm{g} \mathrm{m}^{-1} \mathrm{dur}-$ ing the first $2 \mathrm{~h}$ of ebb tide) and highest tide level. (C) Number of fish eggs $\times 10^{3} \mathrm{~m}^{-1}$ during the first $2 \mathrm{~h}$ of ebb tide, round eggs and spindle-shaped eggs tallied separately

smaller than copepods captured in Ocean Flood nets (Table 1), presumably because of selective feeding on large copepods by planktivorous fishes at the forereef (Emery 1968, 1973, Hobson \& Chess 1978, Hamner et al. 1988, Heidelberg et al. 2004).

Table 1. Zooplankton imported onto and exported from reef in $6 \mathrm{~h}$ on flood and ebb tides (Ocean Ebb-2: first $2 \mathrm{~h}$, ebb tide; Ocean Ebb-4: last $4 \mathrm{~h}$, ebb tide; $\mathrm{n}$ : number of samples). Wet weight in $\mathrm{g}$ : mean wet weight per linear meter of reef; wet weight in mg $\mathrm{m}^{-3}$ : wet weight per $\mathrm{m}^{3}$ of water. Values are means $\pm \mathrm{SD}$. Dominant plankton collected at each location in bold type

\begin{tabular}{|c|c|c|c|c|c|}
\hline & $\mathrm{n}$ & $\begin{array}{c}\text { Wet wt } \\
\text { (g m}{ }^{-1} \text { reef) }\end{array}$ & $\begin{array}{l}\text { Water speed } \\
\left(\mathrm{cm} \mathrm{s}^{-1}\right)\end{array}$ & $\begin{array}{l}\text { Wet wt } \\
\left(\mathrm{mg} \mathrm{m}^{-3}\right)\end{array}$ & Plankton collected \\
\hline Ocean Ebb-2 & 31 & $75.0 \pm 44.8$ & $4.9 \pm 2.7$ & $277.3 \pm 177.4$ & Fish eggs, zoea \\
\hline Ocean Ebb-4 & 15 & $20.8 \pm 5.7$ & $3.8 \pm 1.8$ & $36.3 \pm 16.4$ & Fish eggs, foraminifera, copepods, zoea \\
\hline Ocean Flood & 9 & $71.7 \pm 63.0$ & $1.4 \pm 1.1$ & $299.5 \pm 263.9$ & Large copepods ${ }^{\text {a }}$, appendicularians, chaetognaths, fish eggs \\
\hline Lagoon Flood & 6 & $43.1 \pm 19.9$ & $6.2 \pm 3.7$ & $40.7 \pm 21.5$ & Small copepods ${ }^{\mathbf{b}}$, small chaetognaths, larvaceans, zoea \\
\hline Lagoon Ebb & 9 & $158.4 \pm 85.6$ & $14.2 \pm 6.3$ & $51.9 \pm 23.5$ & Small copepods, zoea, crustacean larvae, chaetognaths \\
\hline
\end{tabular}


Table 2. Percentage of individuals per zooplankton category collected at each sampling location, ordinated by relative abundance for Ocean Ebb samples. The last 5 categories (italics) were considered rare, and were not used for community statistical analyses (n: number of samples)

\begin{tabular}{|c|c|c|c|c|c|c|c|c|c|c|}
\hline \multirow[b]{3}{*}{ Fish eggs } & \multicolumn{2}{|c|}{ Ocean Ebb-2 } & \multicolumn{2}{|c|}{ Ocean Ebb-4 } & \multicolumn{2}{|c|}{ Ocean Flood } & \multicolumn{2}{|c|}{ Lagoon Flood } & \multicolumn{2}{|c|}{ Lagoon Ebb } \\
\hline & \multicolumn{2}{|c|}{$(n=15)$} & \multicolumn{2}{|c|}{$\begin{array}{l}\text { Mean } \\
(\mathrm{n}=6)\end{array}$} & \multicolumn{2}{|c|}{$\begin{array}{l}\text { Mean } \\
(\mathrm{n}=6)\end{array}$} & \multicolumn{2}{|c|}{$\begin{array}{l}\text { Mean } \\
(\mathrm{n}=5)\end{array}$} & \multicolumn{2}{|c|}{$\begin{array}{l}\text { Mean } \\
(\mathrm{n}=9)\end{array}$} \\
\hline & 89.29 & 14.23 & 58.53 & 24.28 & 6.55 & 6.63 & 2.30 & 2.46 & 10.13 & 9.41 \\
\hline Appendicularians & 0.52 & 0.72 & 2.20 & 3.01 & 29.01 & 18.75 & 9.44 & 6.24 & 6.31 & 8.06 \\
\hline Chaetognaths & 0.34 & 0.42 & 1.36 & 2.29 & 26.51 & 11.84 & 11.21 & 4.36 & 15.50 & 10.52 \\
\hline Cladocerans & 0.02 & 0.04 & 0.11 & 0.26 & 2.27 & 4.28 & 0.53 & 0.78 & 0.02 & 0.05 \\
\hline Copepods & 1.95 & 1.72 & 7.69 & 7.15 & 29.90 & 9.85 & 66.39 & 7.94 & 24.13 & 14.93 \\
\hline Zoea & 5.09 & 12.15 & 9.00 & 14.64 & 0.21 & 0.40 & 3.22 & 2.12 & 21.40 & 14.72 \\
\hline Fish larvae & 0.08 & 0.14 & 0.11 & 0.28 & 0.00 & 0.00 & 0.23 & 0.44 & 0.09 & 0.14 \\
\hline Foraminifera & 1.69 & 3.20 & 15.29 & 20.19 & 0.52 & 1.16 & 1.80 & 1.00 & 0.16 & 0.33 \\
\hline Medusae & 0.10 & 0.18 & 0.00 & 0.00 & 1.43 & 1.80 & 2.04 & 0.90 & 0.00 & 0.00 \\
\hline Crustacean larvae & 0.45 & 0.74 & 4.70 & 6.26 & 0.67 & 1.63 & 0.00 & 0.00 & 20.11 & 22.12 \\
\hline Siphonophores & 0.00 & 0.00 & 0.18 & 0.44 & 0.56 & 0.58 & 0.45 & 0.45 & 0.00 & 0.00 \\
\hline Veligers & 0.07 & 0.21 & 0.11 & 0.26 & 0.81 & 1.57 & 1.22 & 0.79 & 1.72 & 2.93 \\
\hline Misc. crustaceans & 0.35 & 1.29 & 0.67 & 1.04 & 1.07 & 0.98 & 0.99 & 1.02 & 0.32 & 0.50 \\
\hline
\end{tabular}

\section{Export of zooplankton from the lagoon and barrier reef on ebb tides}

During ebb tide, lagoon water flowed onto and across the reef $\left(14.2 \pm 6.3 \mathrm{~cm} \mathrm{~s}^{-1}\right)$, transporting $51.9 \pm$ $23.5 \mathrm{mg}$ zooplankton $\mathrm{m}^{-3}$. During the $6 \mathrm{~h}$ ebb period, the biomass of zooplankton transported from lagoon to barrier reef was $158.4 \pm 85.6 \mathrm{~g} \mathrm{~m}^{-1}$ (Lagoon Ebb, Table 1). Lagoon water (Lagoon Ebb, Tables 1 \& 2) contained small copepods $(24.1 \%)$, zoea $(21.4 \%)$, crustacean larvae $(20.1 \%)$, chaetognaths $(15.5 \%)$, fish eggs $(10.1 \%)$, and appendicularians (6.3\%), typical of coral reef lagoons (Emery 1968, Tranter \& George 1972, Hobson \& Chess 1978, 1979). Most fish eggs from the lagoon had developed embryos, were unfertilized (opaque), or were decomposing (fungal growths). The wet weights of lagoon mesozooplankton were highest at new and full moon, due to zoea and larval crustaceans.

At the seaward side of the reef, the biomass of zooplankton flowing off the reef into the ocean over an entire $6 \mathrm{~h}$ ebb tide was $95.8 \pm 35.4 \mathrm{~g} \mathrm{~m}^{-1}$. During the first $2 \mathrm{~h}$ of ebb tide (Ocean Ebb-2), zooplankton from reef to sea was primarily composed of eggs spawned by herbivorous fish at the forereef (75.0 $\pm 44.8 \mathrm{~g} \mathrm{~m}^{-1}$; $89 \%$ eggs; Table 2). During the last $4 \mathrm{~h}$ of ebb tide (Ocean Ebb-4), less zooplankton was captured $(20.8 \pm 5.7 \mathrm{~g}$ $\mathrm{m}^{-1}$ ), with fewer fish eggs (Tables 1 \& 2), and, although flow rates did not decrease significantly, biomass per cubic meter was much lower. Most plankton, therefore, was exported seaward during the first $2 \mathrm{~h}$ of ebb tide in the form of meroplanktonic fish eggs. Although lagoon waters that flowed onto the back reef during ebb tide contained $60 \%$ copepods, zoea, and crustacean larvae, very few of these were captured in seaward nets (except zoea, twice); lagoon zooplankton were either captured by reef planktivores or settled in transit.

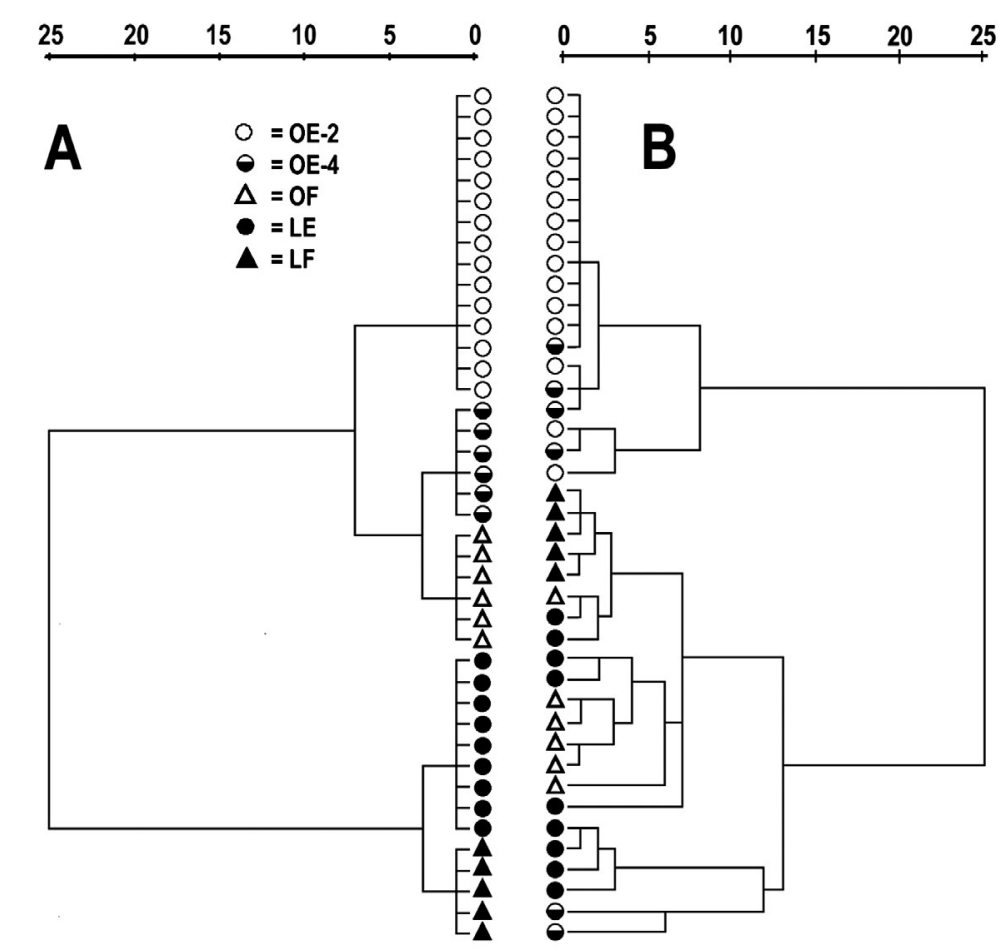

Fig. 5. Dendrograms of zooplankton by stations (A) and samples (B). OE: Ocean Ebb; OF: Ocean Flood; LE: Lagoon Ebb; LF: Lagoon Flood; for further details see Table 1 
Lagoon plankton, therefore, were imported into the reef economy, whereas eggs spawned at the forereef by herbivorous fish during the first $2 \mathrm{~h}$ of ebb tide were exported from the reef to the sea.

Our largest net sample of zooplankton was collected from 1 net offshore during the first $2 \mathrm{~h}$ of ebb tide on 28 July. It collected $>300000$ round surgeonfish eggs $\left(236.0 \mathrm{~g} \mathrm{~m}^{-1}\right.$ in $\left.2 \mathrm{~h}^{-1} ; 600.5 \mathrm{mg} \mathrm{m}^{-3}\right)$, but not a single spindle-shaped parrotfish egg or any other live zooplankton. On the first days of full and new moon, crab zoea contributed a substantial percentage to the ebb tide catch (e.g. Ocean Ebb-4, 15 July, zoea $43.7 \%$ ).

The flux of water across the barrier reef for the first $2 \mathrm{~h}$ of ebb tides was plotted using the faster of the current meters in the paired plankton nets, with greatest flow after full moon and least during first quarter. We also measured water flow across the reef crest adjacent to a large, recurrent aggregation of spawning reef fish. Flow recorded atop the reef crest was faster than in the seaward nets, but both exhibited lunar periodicities in water velocity (Fig. 4A). Increased flow rates across the reef during spring tides suggested that more zooplankton would be transported across the reef during spring tides, so we plotted biomass of exported zooplankton during the first $2 \mathrm{~h}$ of ebb tide for the entire lunar cycle, with wet weights normalized to $120 \mathrm{~min}$ (Fig. 4B). We did not find a statistically significant lunar periodicity for zooplankton biomass because of biomass variability of up to 5-fold between successive days (12 to 13 July; 28 to 29 July). Ebb tide abundance of surgeonfish and parrotfish eggs was plotted separately (Fig. 4C); both groups of fishes exhibited highly significant lunar spawning rhythms. Surgeonfish spawned near high high-water spring tides in late afternoon, with peak spawning on 12 July at 17:32 h, on 28 July at 17:39 h, and on 10 August at 17:00 h, 4 or $5 \mathrm{~d}$ prior to new and full moon. Parrotfish spawned in the morning after high tide, but also throughout the day, primarily during neap tides (Colin \& Bell 1991, Domeier \& Colin 1997).

During the last $4 \mathrm{~h}$ of ebb tide, wet weight of zooplankton exported from the reef was much lower than during the first $2 \mathrm{~h}$ (Table 1). The taxonomic composition of the catch during the last $4 \mathrm{~h}$ of ebb tide was still dominated by fish eggs (58.5\%), although some eggs collected during the last $4 \mathrm{~h}$ of ebb tide had advanced embryos or were coated with fungus. These eggs were not recently spawned, but apparently had advected across the reef flat from the lagoon. When we compared the first $2 \mathrm{~h}$ and last $4 \mathrm{~h}$ of ebb tide, we found that $98.5 \%$ of the spindle-shaped parrotfish eggs and $77.9 \%$ of the round surgeonfish eggs were captured during the first $2 \mathrm{~h}$ of ebb tide. During the last $4 \mathrm{~h}$ of ebb tide, benthic foraminiferans were the second most important category collected, followed by zoea and copepods (Table 2). Crab zoea and larval crustaceans were important components of late ebb tide samples,

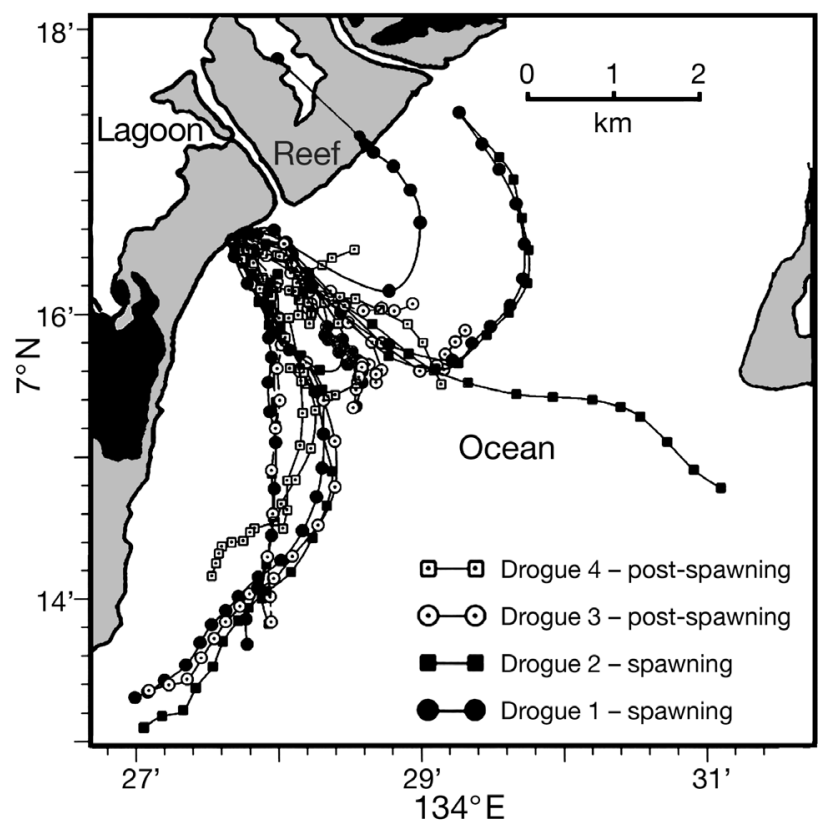

Fig. 7. Movement of drogues released after high tide from the seaward edge of Lighthouse Reef. Drogues advected southeast, but changed direction $6 \mathrm{~h}$ later at flood tide 
but were abundant only following full and new moon. As the tide ebbs, waves resuspend more reef material because the waves are closer to the reef's surface. All late ebb tide samples contained reef debris, crustacean exoskeletons, copepod fecal pellets, and algae.

Dendrograms of samples and station relationships (Fig. 5) show that zooplankton collected during ebb tide on the ocean side of the barrier reef (Ocean Ebb-2, Ocean Ebb-4) were similar to each other; this is not surprising since these 2 groups were temporal subdivisions of the same location and tidal phase. A multidimensional scaling plot (Fig. 6) also shows these similarities, with all Ocean Ebb samples clustered together. However, samples in the first $2 \mathrm{~h}$ differed significantly from those in the last $4 \mathrm{~h}$, because the latter contained fewer fish eggs and because lagoon waters had crossed the reef by the last $4 \mathrm{~h}$ of ebb tide, carrying some lagoon plankton, zoea, and foraminifera. The flood tide samples are somewhat intermixed in the sample dendrogram (Ocean Flood, Lagoon Flood; Fig. 5B) because both sample locations were dominated by copepods, appendicularians, and chaetognaths on flood tides. However, cluster analysis (Fig. 6) shows these 2 sets of samples to be distinctive. Ocean Flood samples collected seaward of the wall of planktivorous fishes contained large copepods, appendicularians, chaetognaths, doliolids, and siphonophores typical of oceanic water (Emery 1968, Hobson \& Chess 1978, Hamner et al. 1988, Sorokin 1990). Importantly, there were also substantial numbers of eggs (6.5\%) identical in size and shape to those spawned on ebb tides by the reef fishes at our study site. These eggs, however, were not recently spawned, but had visible embryos, spawned roughly $12 \mathrm{~h}$ earlier, apparently retained in coastal boundary waters and returned to the reef. Lagoon Ebb samples (LE; Fig. 5) were taxonomically diverse and evenly represented, with small copepods $(30 \%)$, crab zoea $(24 \%)$, chaetognaths (18\%), shrimp larvae (14\%), and fish eggs (10\%). Crab zoea and larvae were only abundant in Lagoon Ebb waters, so they must have been produced by lagoon crabs. Appendicularians were abundant (6 to $11 \%$ ) in 5 of 9 Lagoon Ebb samples.

\section{Drifters and returning eggs}

We released drogues amid the clouds of fish eggs at the forereef (Fig. 7), tracking drogues as proxies of fish eggs, because it is difficult to track recently spawned eggs and/or larvae at sea (but see Willis \& Oliver 1990). Drogues drifted seaward only 2 to $3 \mathrm{~km}$ during ebb tide, and all but 1 drogue reversed or changed direction when the tide began to flood. Oscillatory movements of drogues defined a tidal, neritic, water mass that remained near the barrier reef. This water mass was separated from the equatorial currents around the archipelago by fronts and small-scale and meso-scale eddies visible from small boats and from airplanes on calm days. The nature of entrained, tidal waters has not been well investigated (Kingsford et al. 1991, Wolanski \& Spagnol 2000, Zeidberg \& Hamner 2002), but fronts between tidal waters and the surrounding oceanic currents create hydrographic barriers around oceanic islands that permit neritic waters to act as nurseries for fish and invertebrates that have pelagic developmental stages in their early life history (Leis 1982, Willis \& Oliver 1990, Kingsford et al. 1991).

Many of our surface drogues released at the reef front during ebb tide returned to the vicinity of the reef and/or reentered the lagoon $12 \mathrm{~h}$ later on the flood tide (Fig. 7). Some fish eggs spawned on the previous high tide also returned (6.6\%; Ocean Flood, Table 2). It is important to clarify that these returning eggs were indeed eggs of the fish that had spawned some $12 \mathrm{~h}$ earlier at or close to our study site. All plankton was identified and counted using a microscope with sufficient resolution to discern quite subtle differences in egg shape, size, color, and location of oil droplets and embryos for different species of fish. Most of these imported eggs would be eaten during the day at the forereef (see fish gut data in Hamner et al. 1988), but some eggs crossed the reef and entered the lagoon (eggs 2.3\%; Lagoon Flood, Table 2). Eggs spawned during the day would usually return to the reef 10 to $12 \mathrm{~h}$ later at night, when eggs would be hard to see. Most returning eggs were healthy, with early-stage developing embryos. The return of drogues and recently spawned fish eggs to their natal reef supports the hypothesis that neritic waters, probably entrained by topographic fronts and eddies, enhance self-recruitment (Willis \& Oliver 1990, Kingsford et al. 1991, Jones et al. 1999, Swearer et al. 1999).

\section{Cross-reef flow and zooplankton dynamics}

Flow across coral reefs is controlled by reef height and morphology, wind, wave-overtopping, tides, or a combination of these (Atkinson et al. 1981, Pickard 1986, Hamner \& Wolanski 1988, Wolanski \& Hamner 1988). On the ocean side of the barrier reef, at or near low tide, the water column has no density gradient to depths of at least 15 to $20 \mathrm{~m}$. As rising tide drives flow onto the barrier reef, the entire water column (10 m or more in depth) feeds the shallow reef flat. As water moves onto the reef front, current speed increases compared to speed of currents in deeper water offshore (Roberts \& Suhayda 1983, Hamner et al. 1988). Flood tide flow offshore of Lighthouse Reef was only 
$1.4 \mathrm{~cm} \mathrm{~s}^{-1}$, considerably less than where the reef was shallower and flow averaged $6.2 \mathrm{~cm} \mathrm{~s}^{-1}$.

Ebb tide flow dynamics differ because lagoon water is warmer and/or less saline than ocean water. When lagoon water flowed onto the reef, it was vertically compressed and moved rapidly $\left(14.2 \mathrm{~cm} \mathrm{~s}^{-1}\right)$. At the forereef the less dense lagoon water flowed out to sea in a 2 to $3 \mathrm{~m}$ surface layer. The ebb tide speed of this shallow layer seaward of the forereef was faster than the current at the same spot during rising tides (Ocean Ebb-2, $4.9 \mathrm{~cm} \mathrm{~s}^{-1}$; Ocean Ebb-4, $3.8 \mathrm{~cm} \mathrm{~s}^{-1}$; Ocean Flood, $1.4 \mathrm{~cm} \mathrm{~s}^{-1}$; Table 1).

It is also clear that the assemblage of plankton in a given body of water changes qualitatively and quantitatively, gradually or abruptly, as it flows across the reef. When oceanic or neritic water flows onto the forereef during the day, schools of planktivorous fish abruptly remove larger zooplankton (Emery 1968, 1973, Hamner et al. 1988). Thereafter, the water flows over the reef crest, where breaking waves break loose filamentous algae and resuspend sediments from the reef surface, abruptly adding new particulate materials to the reeftop water column. This water then flows across the reef flat, where grazing fishes gradually resuspend even more materials (Alongi 1997, Crossman et al. 2001, Yahel et al. 2002). This water finally flows into the lagoon, where it quickly mixes with lagoon water. During ebb tide, mesozooplankton composition in lagoon water similarly changes when it flows across the reef, gradually depleted of prey by planktivores and filter feeders, then abruptly enriched at the forereef during the day by a massive infusion of fish eggs. Lastly, the water flowing off the reef into the sea is buoyant (warmer or less saline) and the original parcel of lagoon water, now enriched by fish eggs and zoea, advects offshore as a floating lens rich in neuston that becomes concentrated into buoyant, convergent fronts and slicks formed by tides and topographic eddies (Wolanski \& Hamner 1988, Willis \& Oliver 1990, Kingsford et al. 1991, Wolanski \& Spagnol 2000, Parnell 2001, Wolanski et al. 2003).

The dynamics of cross-reef flow therefore markedly affect the quantity of food potentially available to coral reef organisms, and it is clear that there is far more plankton available to coral reefs than implied by the older literature (Odum \& Odum 1955, Johannes et al. 1972, Johannes \& Gerber 1974). For example, our offshore zooplankton biomass measurements in Palau were approximately $300 \mathrm{mg} \mathrm{m}^{-3}$, similar to published data on standing stock near coral reefs (Tranter \& George 1972, Sammarco \& Crenshaw 1984, Hamner et al. 1988, Sorokin 1990). These relatively robust estimates for offshore mesozooplankton biomass, however, must be multiplied by volume flow across the reef, which is often enormous. For example, at Enewe- tak, Johannes \& Gerber (1974) estimated that 18100 to $33000 \mathrm{~m}^{3}$ of water (devoid of zooplankton by the time it reached their nets atop the reef) flowed across each linear meter of forereef at their transect location every $12 \mathrm{~h}$. Pickard (1986) calculated that $6000 \mathrm{~m}^{3}$ flowed across each meter of forereef at Davies Reef in $12 \mathrm{~h}$,

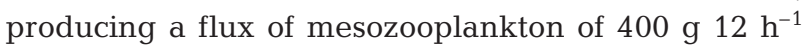
$\mathrm{m}^{-1}$ (Hamner et al. 1988). In Palau, flood tides trans-

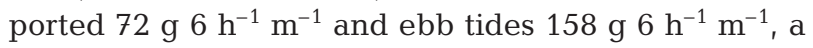


Reef are enriched by similar quantities of imported zooplankton despite hydrographic differences, but


plankton, primarily fish eggs, on ebb tide into the sea.

Coral reefs were originally considered conservative recyclers of materials (Odum 1953, Odum \& Odum 1955), but vast amounts of fish eggs are exported from Palau reefs every day, all year long (P. L. Colin pers. obs.). Although a seemingly flagrant waste of materials valuable to reef organisms, exporting buoyant eggs from reefs full of egg predators is advantageous to the fish (Colin \& Bell 1991, Domeier \& Colin 1997, Craig 1998). Neritic waters apparently retain the eggs long enough for larvae to become behaviorally competent and remain near natal reefs prior to settlement (Leis 1982, Kingsford et al. 1991, Hearn et al. 2000, Wolanksi \& Spagnol 2000, Parnell 2001, Zeidberg \& Hamner 2002). Thereafter, other factors limit settlement of fish larvae on the reef (Doherty et al. 2004). Clearly, export of materials and energy from the forereef and residence times of larval fish in neritic waters must be reexamined (Hatcher 1997).

Acknowledgements. We thank John Carleton for his advice on statistical procedures, Amatzia Genin for reading a very rough early draft, and 9 anonymous reviewers for helpful suggestions and almost never conflicting advice.

\section{LITERATURE CITED}

Alongi DM (1997) Coastal ecosystem processes. CRC Press, Boca Raton, FL

Atkinson MJ, Smith SV, Stroup ED (1981) Circulation in Enewetak Atoll lagoon. Limnol Oceanogr 26:1074-1083

Birkeland C (1982) Terrestrial runoff as a cause of outbreaks of Acanthaster planci (Echinodermata: Asteroidea). Mar Biol 69:175-185

Carleton JH, Brinkman R, Doherty PJ (2001) Zooplankton community structure and water flow in the lee of Helix Reef (Great Barrier Reef, Australia). Mar Biol 139:705-717

Colin PL, Bell LJ (1991) Aspects of the spawning of labrid and scarid fishes (Pisces: Labroidei) at Enewetak Atoll, Marshall Islands with notes on other families. Environ Biol Fish 31:229-260

Craig PC (1998) Temporal spawning patterns of several surgeonfishes and wrasses in American Samoa. Pac Sci 52: $35-39$ 
Crossman DJ, Choat JH, Clements KD, Hardy T, McConochie J (2001) Detritus as food for grazing fishes on coral reefs. Limnol Oceanogr 46:1596-1605

Doherty PJ, Dufour V, Galzin R, Hixon MA, Meekan MG, Planes $S$ (2004) High mortality during settlement is a population bottleneck for a tropical surgeonfish. Ecology 85 : $2422-2428$

Domeier ML, Colin PL (1997) Tropical reef fish spawning aggregations: defined and reviewed. Bull Mar Sci 60: $698-726$

Emery AR (1968) Preliminary observations on coral reef plankton. Limnol Oceanogr 13:293-303

Emery AR (1973) Comparative ecology and functional osteology of fourteen species of damselfish (Pisces: Pomacentridae) at Alligator Reef, Florida Keys. Bull Mar Sci 23: 649-770

Fabricius KE, Metzner J (2004) Scleractinian walls of mouths: predation on coral larvae by corals. Coral Reefs 23: 245-248

Hamner WM, Carleton JH (1979) Copepod swarms: attributes and role on coral reefs. Limnol Oceanogr 24:1-14

Hamner WM, Wolanski E (1988) Hydrodynamic forcing functions and biological processes on coral reefs: a status review. In: Proc 6th Int Coral Reef Symp, Vol 1. Symposium Executive Committee, Townsville, p 103-113

Hamner WM, Jones MS, Carleton JH, Hauri IR, Williams DMcB (1988) Zooplankton, planktivorous fish, and water currents on a windward reef face: Great Barrier Reef, Australia. Bull Mar Sci 42:459-479

Hatcher BG (1997) Organic production and decomposition. In: Birkeland C (ed) Life and death of coral reefs. Chapman and Hall, New York, p 230-248

Hearn CJ, Black R, Johnson MS, Hatcher BG (2000) Modeling gene currents between coral reef islands. In: Proc 9th Int Coral Reef Symp, Vol 1. Indonesian Institute of Science, Jakarta, p 301-303

Heidelberg KB, Sebens KP, Purcell JE (2004) Composition and sources of near reef zooplankton on a Jamaican forereef along with implications for coral feeding. Coral Reefs 23:263-276

Hobson ES, Chess JR (1978) Trophic relationships among fishes and plankton in the lagoon at Enewetak Atoll, Marshall Islands. Fish Bull 76:133-153

Hobson ES, Chess JR (1979) Zooplankters that emerge from the lagoon floor at night at Kure and Midway Atolls. Fish Bull 77:275-280

Holzman R, Genin A (2003) Zooplanktivory by a nocturnal coral-reef fish: effects of light, flow, and prey density. Limnol Oceanogr 48:1367-1375

Johannes RE, Gerber R (1974) Import and export of net plankton by an Eniwetok coral reef community. In: Proc 2nd Int Coral Reef Symp, Vol 1. Great Barrier Reef Committee, Brisbane, p 97-104

Johannes RE, Alberts J, D'Elia C, Kinzie RA and 19 others (1972) The metabolism of some coral reef communities: a team study of nutrient and energy flux at Eniwetok. BioScience 22:541-543

Jones GP, Milicich MJ, Emslie MJ, Lunow C (1999) Selfrecruitment in a coral reef fish population. Science 402: 802-804

Kingsford MJ, Wolanski E, Choat JH (1991) Influence of tidally induced fronts and Langmuir circulation on distribution and movements of presettlement fishes around a

Editorial responsibility: Charles Birkeland (Contributing Editor), Honolulu, Hawaii, USA coral reef. Mar Biol 109:167-180

Kinsey DW (1991) The coral reef: an owner-built, highdensity, fully-serviced, self-sufficient housing estate in the desert-Or is it? Symbiosis 10:1-22

Legendre P, Gallagher ED (2001) Ecologically meaningful transformations for ordination of species data. Oecologia 129:271-280

Leis JM (1982) Nearshore distributional gradients of larval fish (15 taxa) and planktonic Crustacea (6 taxa) in Hawaii. Mar Biol 72:89-97

Odum EP (1953) Fundamentals of ecology. W. B. Saunders, Philadelphia, PA

Odum HT, Odum EP (1955) Trophic structure and productivity of a windward coral reef community on Eniwetok Atoll. Ecol Monogr 25:291-320

Omori M, Ikeda T (1984) Methods in marine zooplankton ecology. John Wiley \& Sons, New York

Parnell PE (2001) The distribution of estuarine and oceanic water masses on the southern shore of O'ahu, Hawai'i: ecological and coastal management implications, and novel methodology. Limnol Oceanogr 46:1468-1485

Pickard GL (1986) Effects of wind and tide on upper-layer currents at Davies Reef, Great Barrier Reef, during MECOR (July-August 1984). Aust J Mar Freshw Res 37 : 545-565

Roberts HH, Suhayda JN (1983) Wave-current interactions on a shallow reef (Nicaragua, Central America). Coral Reefs 1:209-214

Sammarco PW, Crenshaw H (1984) Plankton community dynamics of the Great Barrier Reef Lagoon: analysis of data from Ikeda et al. Mar Biol 82:167-180

Sorokin YuI (1990) Plankton in reef ecosystems. In: Dubinsky Z (ed) Ecosystems of the world, Vol 25 Coral reefs. Elsevier, Amsterdam, p 291-327

Swearer SE, Casselle JE, Lea DW, Warner RW (1999) Larval retention and recruitment in an island population of a coral reef fish. Science 402:799-802

Tranter DJ, George J (1972) Zooplankton abundance at Kavaratti and Kalpeni Atolls in the Laccadives. In: Proc 1st Symp Corals and Coral Reefs. Marine Biology Association of India, Cochin, p 239-256

Willis BL, Oliver JK (1990) Direct tracking of coral larvae: implications for dispersal studies of planktonic larvae in topographically complex environments. Ophelia 32: 145-162

Wolanski E, Hamner WM (1988) Topographically controlled fronts in the ocean and their biological influence. Science 241:177-181

Wolanski E, Spagnol S (2000) Sticky waters in the Great Barrier Reef. Estuar Coast Shelf Sci 50:27-32

Wolanski E, Richmond RH, Davis G, Deleersnijder E, Leben RR (2003) Eddies around Guam, an island in the Mariana Islands group. Cont Shelf Res 23:991-1003

Yahel R, Yahel G, Genin A (2002) Daily cycles of suspended sand at coral reefs: a biological control. Limnol Oceanogr 47:1071-1083

Zaitsev YuP (1971) Marine neustonology. Translated from Russian by A. Mercado. US Dept Commerce Natl Tech Inf Serv, Washington, DC

Zeidberg LD, Hamner WM (2002) Distribution of squid paralarvae, Loligo opalescens (Cephalopoda: Myopsida), in the Southern California Bight in the three years following the 1997-1998 El Niño. Mar Biol 141:111-122

Submitted: August 7, 2005; Accepted: June 23, 2006

Proofs received from author(s): February 11, 2007 